\title{
Scale Morphologies of Freshwater Fishes at Tembat Forest Reserve, Terengganu, Malaysia
}

(Morfologi Sisik Ikan Air Tawar di Hutan Simpan Tembat, Terengganu, Malaysia)

\author{
FARAH AyUni FARINORDIN*, WAN SERIBANI WAN NILAM, SHAHRIL MOd Husin, \\ ABDULLAH SAMAT \& SHUKOR MD. NOR
}

\begin{abstract}
Scales are calcium carbonate and collagen-contained structures embedded within the fish epidermis and useful for species identification. This study aimed to describe morphological characteristics of scales and use the differences to prepare keys to species. Fishes were sampled from selected rivers of Tembat Forest Reserve, Hulu Terengganu. Specimens caught were from 3 families (Cyprinidae, Channidae, Nandidae) and 17 species. Each species was represented by ten individuals (size ranges $2.5-50 \mathrm{~cm} \mathrm{TL}$ ). The scales were removed, soaked in $\mathrm{H}_{2} \mathrm{O}_{2}(0.5 \%), \mathrm{NH} 3(0.3 \%), \mathrm{DH}_{2} \mathrm{O}$ and mounted between a pair of glass slides for digital photographing. The morphological descriptions were based on types of scales, distinctiveness of radii arrangement at the anterior field, radii cover, radii distribution, overall shape, focus position and focus pattern. Keys to species were constructed based on these scale morphological characters described. Measurements of scale total length $(L)$, total width $(W)$, rostral field length (L1) and caudal field length (L2) of the scales were taken using Image J software. The inter-specific variation among scales was indicated by $L 1 / L, L 2 / L, L 1 / L 2$ and W/L indices through multiple comparison tests (ANOVA). It was found that all 17 species showed significant differences with at least one other species in all four indices. Pristolepis grootii (Bleeker 1852) was the only one that significantly different $(p<0.05)$ from other 16 species in the first three indices. Species that showed the least significant differences among species was Probarbus jullieni (Sauvage 1880). The differences among the scales were primarily due to the different types of scale that was either ctenoid or cycloid.
\end{abstract}

Keywords: Freshwater fishes; scale morphologies; scale types; Tembat Forest Reserve; Terengganu

\section{ABSTRAK}

Sisik ialah struktur yang mengandungi komponen kalsium karbonat dan kolagen yang terletak di bawah epidermis serta berguna untuk pengecaman spesies. Kajian ini bertujuan untuk menghuraikan ciri morfologi sisik dan menggunakan perbezaan morfologi tersenarai untuk menyediakan kekunci menuju spesies. Pensampelan dijalankan di beberapa batang sungai terpilih di Hutan Simpan Tembat, Hulu Terengganu. Spesimen yang ditangkap terdiri daripada 3 famili, (Cyprinidae, Channidae, Nandidae) dan 17 spesies. Setiap spesies diwakili oleh 10 individu (saiz berukuran daripada 2.5 - $50 \mathrm{~cm} \mathrm{PT).} \mathrm{Sisik} \mathrm{ditanggalkan,} \mathrm{kemudian} \mathrm{direndam} \mathrm{dalam} \mathrm{H}_{2} \mathrm{O}_{2}(0.5 \%), \mathrm{NH}_{3}(0.3 \%), \mathrm{DH}_{2} \mathrm{O}$ dan diapit di antara sepasang slaid kaca untuk diambil gambar digitalnya. Huraian ciri morfologi adalah berdasarkan jenis sisik, susunan jelas jejari di bahagian anterior, litupan jejari, taburan jejari, bentuk keseluruhan sisik, posisi fokus dan corak fokus . Kekunci menuju spesies dibuat berasaskan huraian ciri morfologi tersebut. Pengukuran panjang total $(L)$, lebar total $(W)$, panjang rostrum (L1) dan panjang kaudal (L2) sisik dibuat menggunakan perisian Image J. Variasi inter-spesifik dalam kalangan sisik dilihat melalui indeks L1/L, L2/L, L1/L2 dan W/L melalui ujian analisis perbandingan berganda (ANOVA). Didapati kesemua 17 spesies menunjukkan perbezaan signifikan dengan sekurang-kurangnya satu spesies lain dalam keempat-empat indeks. Pristolepis grootii (Bleeker 1852) merupakan satu-satunya spesies yang berbeza secara signifikan $(p<0.05)$ daripada 16 spesies lainnya dalam 3 indeks pertama yang tersebut, manakala spesies yang menunjukkan perbezaan signifikan paling rendah adalah Probarbus jullieni (Sauvage 1880). Perbezaan utama morfologi sisik dapat dilihat ketara melalui jenis sisik iaitu sama ada jenis sikloid atau ktenoid.

Kata kunci: Ikan air tawar; Hutan Simpan Tembat; jenis sisik; morfologi sisik; Terengganu

\section{INTRODUCTION}

The identification of fish based on phenotypic features such as body morphologies, meristic counts, otolith structure and scale shapes have been widely used (Poulet et al. 2005). External morphologies of fish such as sizes and shapes of fins as well as sizes and shapes of whole bodies are the basic characters used to identify the fish species (Cadrin 2000; Casselman et al. 1981; Ibanez et al. 2007; Ihssen et al.1981). Meanwhile, DNA extraction and amplification are well-known, more advanced and modern method for species verification and determination. However, it is costly, time consuming (Ibanez et al. 2007; Hutchinson et 
al. 2001; Mariani et al. 2005) and cannot be conducted in the field.

Fish scales are hard bony structures that grow shingle-like from pockets within the skin (Schneider et al. 2000). The type of scales varies including the plate-like placoid scales, the diamond shaped ganoid scales, the thin, smooth, disc-like cycloid scales and ctenoid scales with small projection along the posterior margin (Casteel 1976; Patterson et al. 2002). Identification of fish based on their scales had been used since the early 1900s (Goodrich 1909; Ibanez \& O’Higgins 2011). Fish scales are suitable as tools for identification because they are convenient, non-destructive, undigested by mammals' digestive system and less costly compared to molecular techniques (Ibanez et al. 2007). Just like external morphologies of fish, useful taxonomic information also can be gained from scales such as scale types, sizes, radii arrangement, presence of circuli and focus position. These distinguished characteristics can be used to identify species (Harabawy et al. 2012), the age (Esmaeili et al. 2007; Jhingran 1957; Johal 2005; Johal \& Tandon 1992) and sexes of fish (Ganzon et al. 2012).

More freshwater fishes are exposed to extinction as the freshwater ecosystems are highly threatened by anthropogenic activities (April et al. 2011). The impact of deforestation, conversion of land to agriculture, dam construction and use of pesticides and herbicides cause the degradation of watershed (Winemiller et al. 2008). Most countries all over the world have similar major threat; the loss of habitats, which resulting in the reduction of fish stock. Conservation of fish should start with resolving simple, species identification problems and in this study, it focuses on identifying based on fish scales.

Hulu Terengganu district consists of tropical rainforest, situated at the southern part which has been legislated as a part of the Taman Negara National Park with the area of $853 \mathrm{~km}^{2}$ - a region that is rich with biodiversity (Mustafa 2008). A part of Hulu Terengganu region is Tasik Kenyir Development Area that has the area of 209,199 hectares, lies at the longitude of $102^{\circ} 40^{\prime}$ and latitude $4^{\circ} 40^{\prime}$ and managed by Lembaga Kemajuan Terengganu Tengah (KETENGAH). Kenyir Lake, the biggest man-made lake in Southeast Asia, which is set in the heart of the rainforest, stands about $138 \mathrm{~m}$ above sea level, surrounding by rich and valuable flora and fauna. It is situated in the North of Hulu Telemong Forest Reserve and in the South of Hulu Terengganu Forest Reserve that leads to the National Park.

There are many streams that flow into Kenyir Lake such as Sungai Tembat, Sungai Puah, Sungai Petuang, Sungai Siput, Sungai Cacing, Sungai Pertang, Sungai Cicir and Sungai Galong (Mustafa 2008). This study was conducted at four feeder streams of Sungai Puah which were Sungai Deka, Sungai Terengganu Mati, Sungai Sirih, and Sungai Limbang as shown in Figure 1. The objectives of this study were to describe morphological characteristics of fish scales and to use the differences to prepare keys to species.

\section{MATERIALS AND METHODS}

FIELD SAMPLING

Fishes were collected by using backpack electro-fisher model Smith-Root LR-20 and $20 \mathrm{~m}$ gill nets of $6.4 \mathrm{~cm}$ mesh size from four selected streams namely Sungai Deka $\left(\mathrm{N} 05.01816^{\circ}, \mathrm{E} 102.53403^{\circ}\right)$, Sungai Terengganu Mati (N05.164833 $\left.{ }^{\circ}, \mathrm{E} 102.604717^{\circ}\right)$, Sungai Sirih (N05.01860 E102.53207 ${ }^{\circ}$ ) and Sungai Limbang (N05.22042 ${ }^{\circ}$, E102.49857 ${ }^{\circ}$ ) of Tembat Forest Reserve, Hulu Terengganu (Figure 1). They were then sorted, grouped and identified based on their external features as provided from keys described by Kottelat et al. (1993), before transported back to laboratory for scale removal. A total of 360 specimens consisted of 3 families (Cyprinidae, Channidae, Nandidae) and 17 species were examined. Each species was represented by ten individuals with different range of sizes as shown in Table 1. The species were Spotted Barb, Barbodes binotatus (Valenciennes 1842), Siamese Flying Fox, Crossocheilus oblongus Kuhl and Van Hasselt, 1823, Hampala Barb, Hampala macrolepidota Kuhl and Van Hasselt, 1823, River Carp, Lobocheilos rhabdoura (Fowler 1934), Minnow, Mystacoleucus obtusirostris (Valenciennes 1842), Brook Carp, Neolissochilus soroides (Duncker 1904), Bonylip Barb, Osteochilus waandersii (Bleeker 1853), Carp, Poropuntius smedleyi (de Beaufort 1933), Isok Barb, Probarbus jullieni Sauvage, 1880, Spanner Barb, Puntius lateristriga (Valenciennes 1842), Sidestripe Rasbora, Rasbora paviana Tirant, 1885, Sumatran Rasbora, Rasbora sumatrana (Bleeker 1852), Mahseer, Tor tambra (Valenciennes 1842), Red Mahseer, Tor tambroides (Bleeker 1854), Splendid Snakehead, Channa lucius (Cuvier 1831), Common Snakehead, Channa striata (Bloch 1793) and Indonesian Leaffish, Pristolepis grootii (Bleeker 1852).

\section{LABORATORY WORKS AND ANALYSIS}

Scales located below the lateral line, paralleled to the dorsal fin from the left side of the body, were gently removed by using forceps. Care was taken so that specimens were not damaged when removing adhered tissues from the scale. They were then soaked in $0.5 \%$ liquid hydrogen peroxide $\left(\mathrm{H}_{2} \mathrm{O}_{2}\right)$ for $30 \mathrm{~min}$ for cleansing, followed by $0.3 \%$ liquid ammonia $\left(\mathrm{NH}_{3} ; M=17.03 \mathrm{~g} / \mathrm{mol}\right)$ for another $30 \mathrm{~min}$ and rinsed with distilled water before drying. The scales were then mounted between slides and photographed by using a Sony Cybershot 20-megapixels digital camera with black background to enhance the contrast. Amount of light was adjusted to produce a clear image. The images were rendered by using Adobe Photoshop software. The description of the scales were made based on types of scales, distinctiveness of radii arrangement at the anterior field, radii cover, radii distribution, overall shape, focus position and focus pattern. Keys to species were constructed based on the morphological characters described. Measurements of total length (L), total width (W), rostral field length (L1) and caudal field length (L2) of 


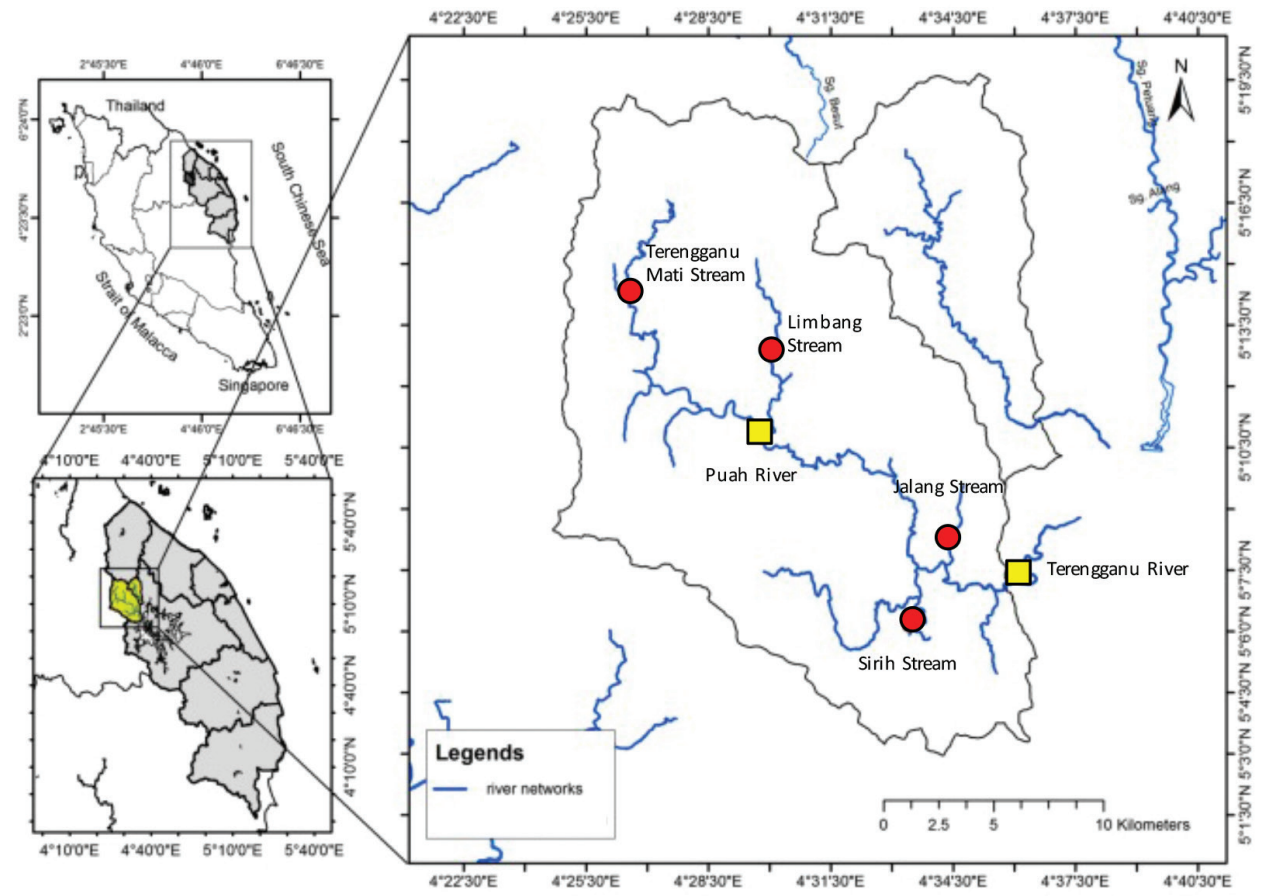

Sampling site

FIGURE 1. Study sites marked with circles; Terengganu Mati Stream, Limbang Stream, Sirih Stream and Jalang Stream

the scale were taken by using Image J software. Based on those measurements, four ratios were estimated relating to length (L); L1/L, L2/L, L1/L2 and W/L. The inter-specific variation among scales was indicated by the values ofL $1 / \mathrm{L}$, $\mathrm{L} 2 / \mathrm{L}, \mathrm{L} 1 / \mathrm{L} 2$ and $\mathrm{W} / \mathrm{L}$ ratios through multiple comparison tests (ANOVA). The indices were analysed by using posthoc test to show inter-specific variations between species. Details about the location of selected fish scale, scale morphological characteristics and the scale measurements are shown in Figure 2.

\section{RESULTS AND DISCUSSION}

There are 3 families altogether, composed of 17 species and Cyprinidae is the family with the most number of species (14 species) followed by Channidae ( 2 species) and Nandidae (1 species). The number of families is low thus keys to families were not constructed. The primary characters observed for identification to species level are type of scale and distinctiveness of radii arrangement specifically at the anterior field. The secondary characters are radii cover, radii distribution, overall scale shape, focus position and focus pattern. Scale images of each species are shown in Figure 3.

There are only two types of scales; ctenoid and cycloid. With the structure of ctenii projected at the posterior or caudal end of the scale, ctenoid type is comparatively easier to be identified. Cycloid type lacks ctenii, discshaped and comparatively thinner. Species belonged to Cyprinidae and Channidae families are cycloid type while Pristolepis grootii which belonged to Nandidae family was the only species with scale of ctenoid type. Scales of Channidae consisted of radii which are distinctively arranged at the anterior field. Channa striata and C. lucius were differentiated by observing the focus position. The focus of $C$. striata is not concentric which contradicted $C$. lucius with its concentric focus position.

The morphological characters of scales belonged to Cyprinidae are minute, more complex and more diverse compared to the other 2 families. The radii structure covering all three fields; anterior, posterior and lateral fields were found in scales of 4 species (Probarbus jullieni, Hampala macrolepidota, Barbodes binotatus and $P$. lateristriga), while for the rest of 10 species, the radii only covered the anterior and posterior fields. The scales of $P$. jullieni showed numerously, closely arranged radii. Key to a single species based on morphological descriptions was developed for 11 species. The rest 6 species were distinguished based on morphometric analysis which include range for $\mathrm{W} / \mathrm{L}$ and $\mathrm{L} 1 / \mathrm{L} 2$ ratios. Those 6 species were B. binotatus, P. lateristriga, T. tambra, T. tambroides, $R$. paviana and $R$. sumatrana. The scales of those species mentioned were hardly distinguishable morphologically as they shared almost similar meristic and morphological characteristics. Scales belonged to $H$. macrolepidota, $B$. binotatus, and P. lateristriga appeared in two variations. The first formation is moderately and symmetrically arranged radii which covered all three fields with a concentric focus in the middle. Another formation is a pair of moderately arranged, branching radii covering all three fields with irregular, non-concentric mosaicpattern focus. Perhaps it was due to scale shape of $H$. 


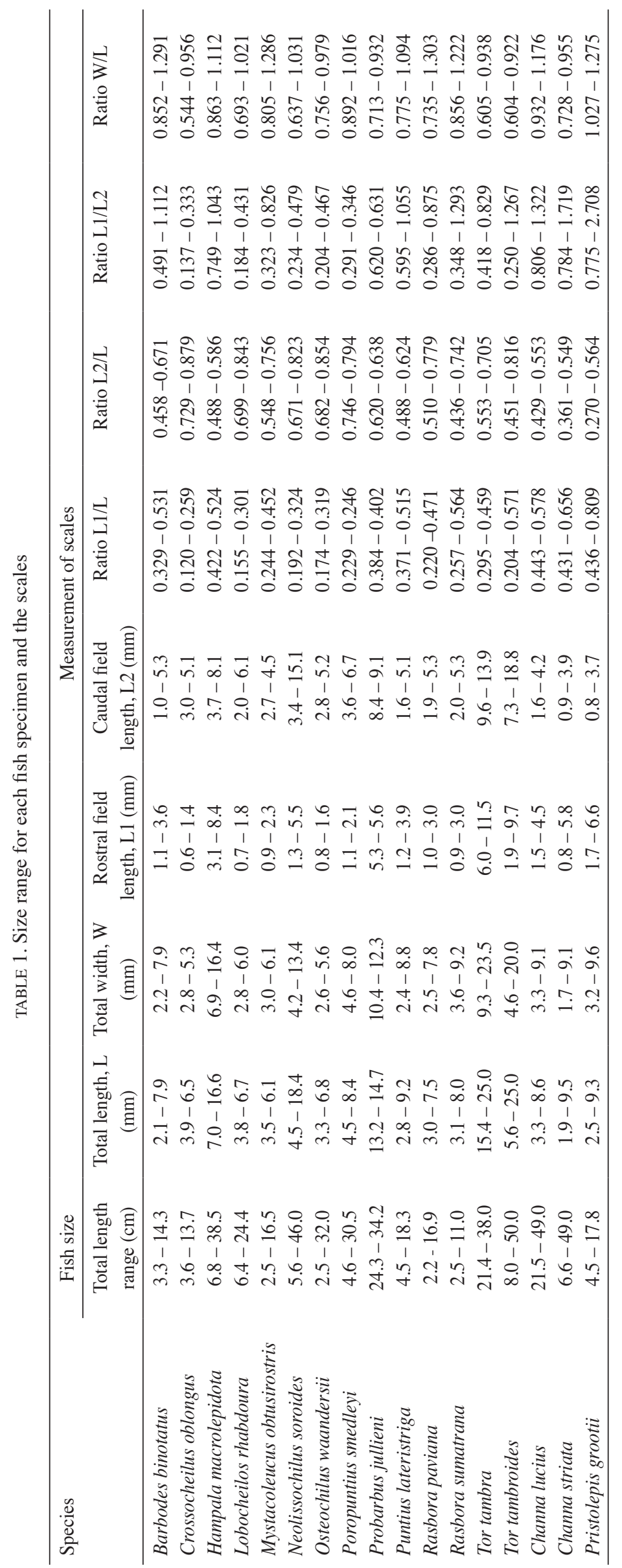


macrolepidota which appeared to be slightly rectangular that distinguished it from B. binotatus and P. lateristriga, while the rest characteristics are almost similar. For scales of $B$. binotatus and P. lateristriga, the overall shapes for both species are square. Both species were distinguished by range of W/L ratio; 0.852 - 1.291 for B. binotatus while
0.775 - 1.094 for B. lateristriga. Details of distinguishable scale morphologies are tabulated in Table 2.

Hexagonally-shaped scales could be observed in Poropuntius smedleyi, Neolissochilus soroides, T. tambra and $T$.tambroides while the non-hexagonal scales belonged to $O$. waandersii, L. rhabdoura, R. paviana, R. sumatrana,
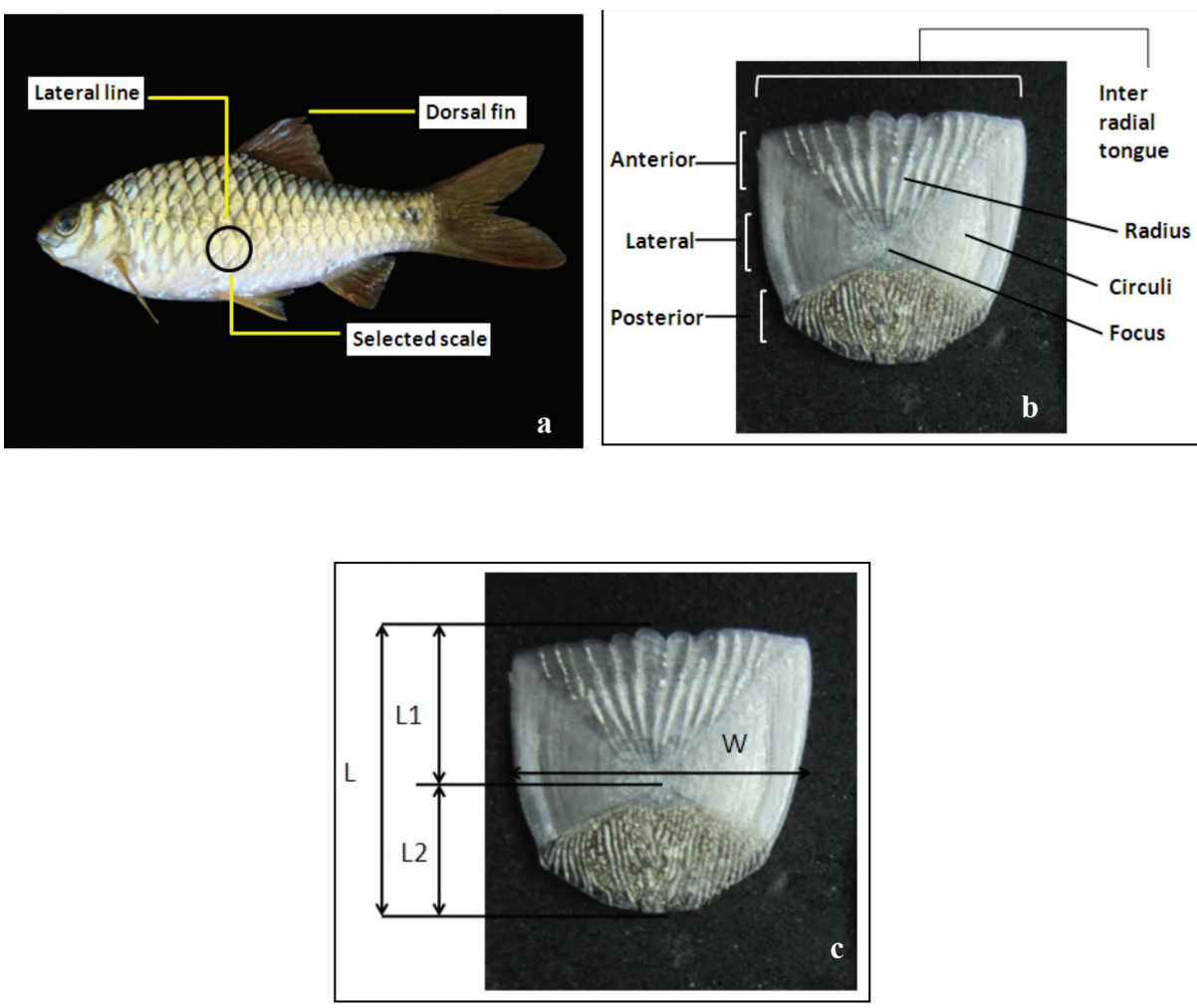

FIGURE 2. (a) Selected scale that is below the lateral line, (b) morphological characteristics of a scale and (c) parameters involved for scale measurements
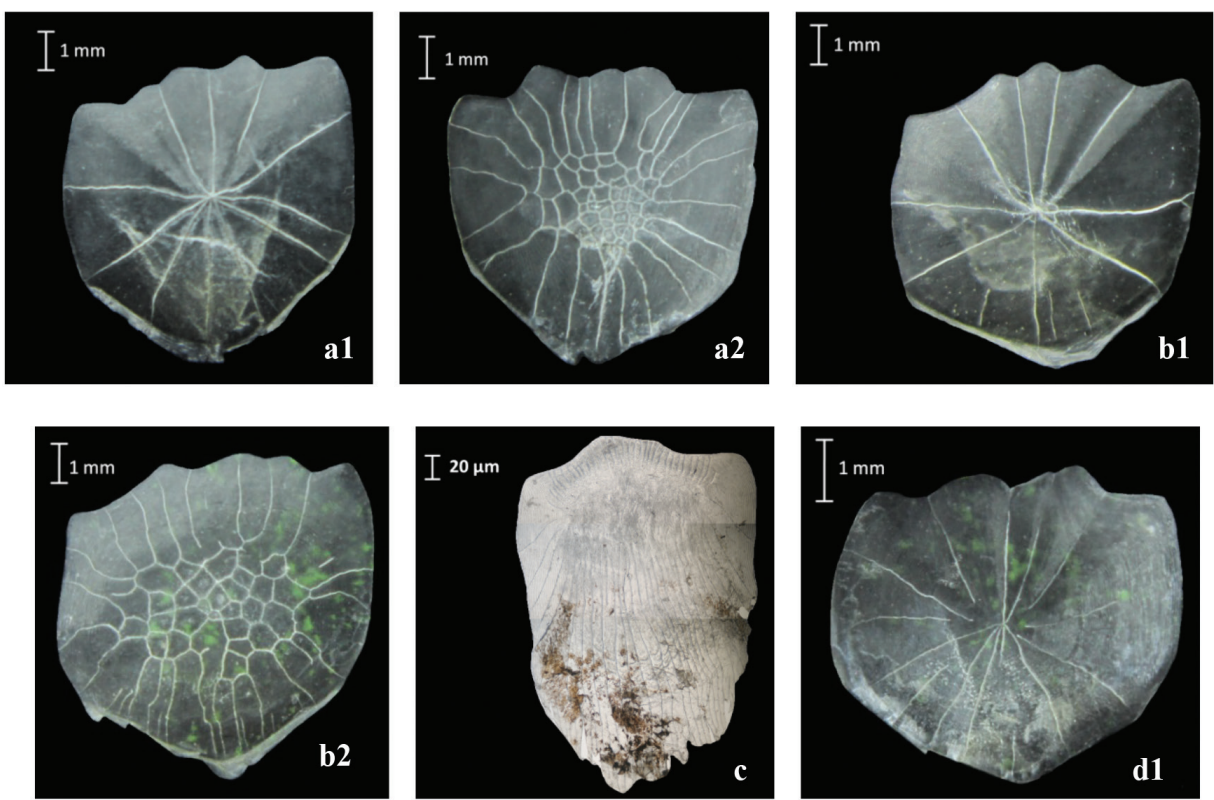

FIGURE 3 (continued) 

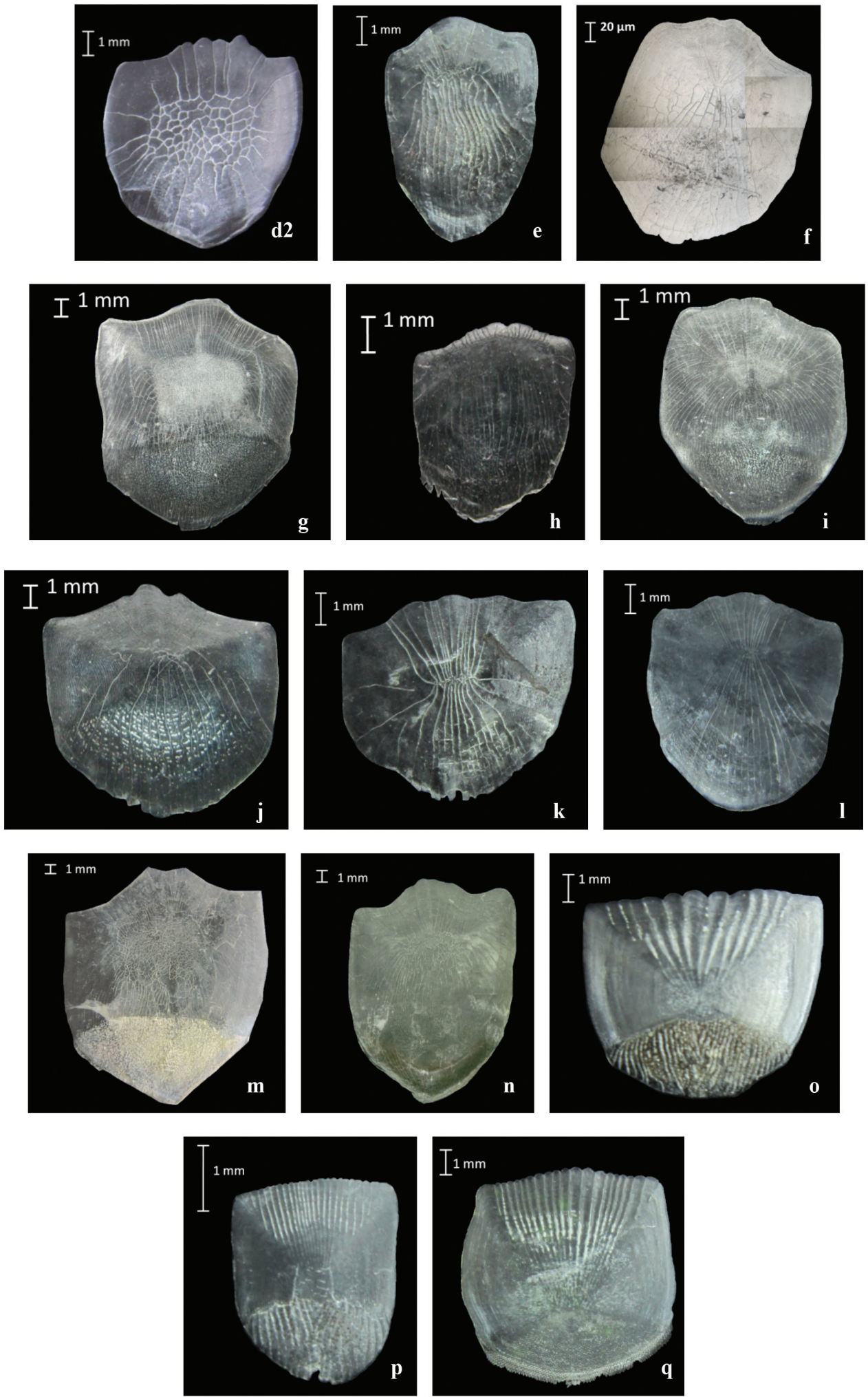

FIGURE 3. Scales of a1) Barbodes binotatus (first variety) a2) Barbodes binotatus (second variety) b1) Puntius lateristriga (first variety) b2) Puntius lateristriga (second variety) c) Crossocheilus oblongus d1) Hampala macrolepidota (first variety) d2) Hampala macrolepidota (second variety) e) Lobocheilos rhabdoura f) Mystacoleucus obtusirostris g) Neolissocheilus soroides h) Osteochilus waandersii i) Probarbus jullieni j) Poropuntius smedleyi $\mathrm{k}$ ) Rasbora paviana 1) Rasbora sumatrana m) Tor tambra n) Tor tambroides o) Channa lucius p) Channa striata and q) Pristolepis grootii 


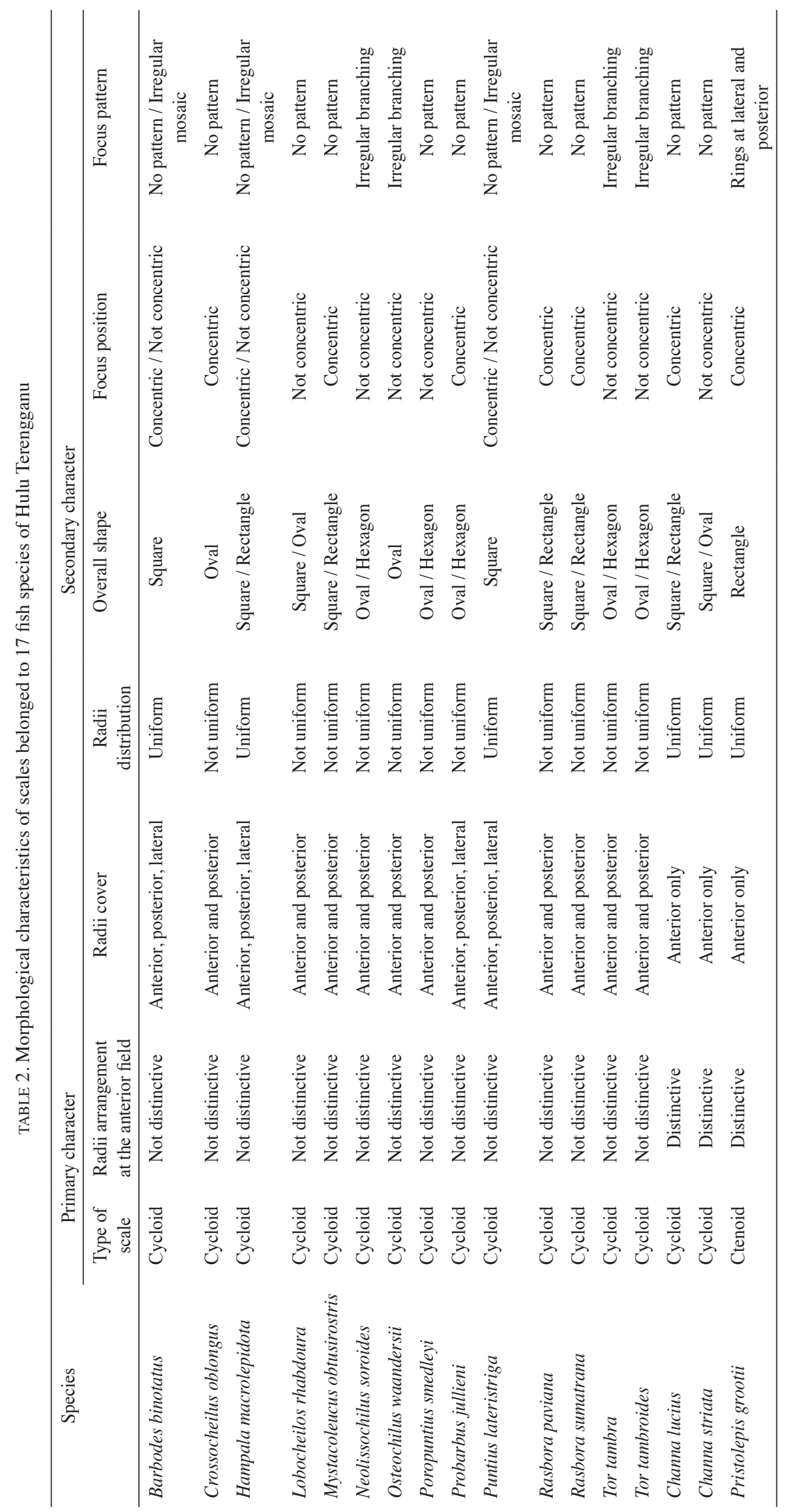


M. obtusirostris and C. oblongus. The focus of scales from $P$. smedleyi has no pattern, unlike the other three hexagonally-shaped species. For $N$. soroides, the focus was formed by irregular, branching pattern while for both T. tambra and T. tambroides, the foci were formed by tiny, irregular netted patterns.

Scales of both M. obtusirostris and C. oblongus were having tiny and closely arranged radii at posterior field. The only good characteristic is the scale shape, with $M$. obtusirostris having rectangular overall shape while for $C$. oblongus, the shape is oval. For both $R$. paviana and $R$. sumatrana, the radii are not closely arranged at posterior. Meanwhile, both $O$. wandersii and L. rhabdoura are not hexagonally-shaped and not having concentric foci. The only difference is irregular branching patterned observed in scales of $O$.waandersii while no focus patterns observed in scales of L. rhabdoura.

Based on the conducted multiple comparison tests (ANOVA - post-hoc) for L1/L, L2/L, L1/L2 and W/L indices, inter-specific variation among scales were obtained. All 17 species showed significant differences $(p<0.05)$ with at least one other species in all four indices (Tables 3 - 6). The scales of Pristolepis grootii are significantly different with scales of most of other species. In the first three ratios, $P$. grootii is the only species that showed significant differences with all of 16 other species while for $\mathrm{W} / \mathrm{L}$ ratio, this species showed significant differences with only 12 other species. Meanwhile, scales of P.jullieni showed the least significant differences with other species. Morphologically, P. grootii was the only species which is of ctenoid type while the other species belonged to cycloid type. The overall scale shape of this species is rectangle and the shape appeared to be consistent in all observed specimens. The $\mathrm{W}$ value is obviously more than the $\mathrm{L}$ value due to its nature shape. Key to species was developed as shown to Table 7.

For a few species which are hardly distinguishable based on morphological descriptions, it is recommended to observe the differences with scanning electron microscope (SEM) in the future thus the development of keys to species would be more accurate. More similar researches are encouraged to describe other morphological characteristics of freshwater fish species, perhaps in different localities to compare the scale morphologies.

The scales from fish species in this study were described based on morphologies, morphometric characteristic and the range of four ratios relating to scale length. Keys to species identification could only be used for those 17 species described but can act as guidelines for future studies, as references for other lepidologists and would be helpful in effort of contemplating conservation of freshwater fishes.

TABLE 3. Multiple comparisons of $\mathrm{L} 1 / \mathrm{L}$ among 17 species of fish that were caught by using Post-Hoc comparison test (Tukey HSD)

\begin{tabular}{|c|c|c|c|c|c|c|c|c|c|c|c|c|c|c|c|c|c|}
\hline \multirow{2}{*}{$\begin{array}{l}\frac{\mathscr{U}}{\tilde{N}} \\
\tilde{\mathscr{N}}\end{array}$} & \multicolumn{17}{|c|}{ Significant value (P value) } \\
\hline & 1 & 2 & 3 & 4 & 5 & 6 & 7 & 8 & 9 & 10 & 11 & 12 & 13 & 14 & 15 & 16 & 17 \\
\hline 1 & & & & & & & & & & & & & & & & & \\
\hline 2 & 0.000 & & & & & & & & & & & & & & & & \\
\hline 3 & 1.000 & 0.000 & & & & & & & & & & & & & & & \\
\hline 4 & 0.000 & 0.315 & 0.000 & & & & & & & & & & & & & & \\
\hline 5 & 0.000 & 0.000 & 0.000 & 0.000 & & & & & & & & & & & & & \\
\hline 6 & 0.000 & 0.000 & 0.000 & 0.417 & 0.092 & & & & & & & & & & & & \\
\hline 7 & 0.000 & 0.180 & 0.000 & 1.000 & 0.008 & 0.986 & & & & & & & & & & & \\
\hline 8 & 0.000 & 0.899 & 0.000 & 1.000 & 0.398 & 1 & 1.000 & & & & & & & & & & \\
\hline 9 & 0.940 & 0.000 & 0.868 & 0.005 & 0.989 & 0.095 & 0.020 & 0.124 & & & & & & & & & \\
\hline 10 & 0.931 & 0.000 & 0.752 & 0.000 & 0.000 & 0.000 & 0.000 & 0.000 & 0.999 & & & & & & & & \\
\hline 11 & 0.000 & 0.000 & 0.000 & 0.000 & 1 & 0.000 & 0.000 & 0.071 & 0.993 & 0.000 & & & & & & & \\
\hline 12 & 0.001 & 0.000 & 0.000 & 0.000 & 0.896 & 0.000 & 0.000 & 0.004 & 1 & 0.110 & 0.752 & & & & & & \\
\hline 13 & 0.528 & 0.000 & 0.365 & 0.000 & 0.897 & 0.001 & 0.000 & 0.014 & 1 & 0.975 & 0.884 & 1 & & & & & \\
\hline 14 & 0.000 & 0.000 & 0.000 & 0.000 & 1.000 & 0.010 & 0.001 & 0.267 & 0.987 & 0.000 & 1 & 0.821 & 0.867 & & & & \\
\hline 15 & 0.788 & 0.000 & 0.987 & 0.000 & 0.000 & 0.000 & 0.000 & 0.000 & 0.432 & 0.075 & 0.000 & 0.000 & 0.053 & 0.000 & & & \\
\hline 16 & 0.000 & 0.000 & 0.000 & 0.000 & 0.000 & 0.000 & 0.000 & 0.000 & 0.013 & 0.000 & 0.000 & 0.000 & 0.000 & 0.000 & 0.528 & & \\
\hline 17 & 0.000 & 0.000 & 0.000 & 0.000 & 0.000 & 0.000 & 0.000 & 0.000 & 0.000 & 0.000 & 0.000 & 0.000 & 0.000 & 0.000 & 0.000 & 0.000 & ....... \\
\hline
\end{tabular}

$*=$ The mean difference is significant at the 0.05 level

Legend: 1= Barbodes binotatus, 2= Crossocheilus oblongus, 3=Hampala macrolepidota, $4=$ Lobocheilos rhabdoura, $5=$ Mystacoleucus obtusirostris, $6=$ Neolissochilus soroides, $7=$ Osteochilus waandersii, $8=$ Poropuntius smedleyi, $9=$ Probarbus jullieni, $10=$ Puntius lateristrig, $11=$ Rasbora paviana, $12=$ Rasbora sumatrana, $13=$ To tambra, 14= Tor tambroides, 15= Channa lucius, 16= Channa striata, $17=$ Pristolepis grootii 
TABLE 4. Multiple comparisons of L2/L among 17 species of fish that were caught by using Post-Hoc comparison test (Tukey HSD)

\begin{tabular}{|c|c|c|c|c|c|c|c|c|c|c|c|c|c|c|c|c|c|}
\hline \multirow{2}{*}{$\begin{array}{l}\frac{\mathscr{s}}{\tilde{U}} \\
\frac{\mathscr{d}}{\sim}\end{array}$} & \multicolumn{17}{|c|}{ Significant value (P value) } \\
\hline & 1 & 2 & 3 & 4 & 5 & 6 & 7 & 8 & 9 & 10 & 11 & 12 & 13 & 14 & 15 & 16 & 17 \\
\hline \multicolumn{18}{|l|}{1} \\
\hline 2 & 0.000 & & & & & & & & & & & & & & & & \\
\hline 3 & 1 & 0.000 & & & & & & & & & & & & & & & \\
\hline 4 & 0.000 & 0.041 & 0.000 & & & & & & & & & & & & & & \\
\hline 5 & 0.000 & 0.000 & 0.000 & 0.000 & & & & & & & & & & & & & \\
\hline 6 & 0.000 & 0.000 & 0.000 & 0.885 & 0.044 & & & & & & & & & & & & \\
\hline 7 & 0.000 & 0.040 & 0.000 & 1 & 0.011 & 1 & & & & & & & & & & & \\
\hline 8 & 0.000 & 0.991 & 0.000 & 1 & 0.098 & 0.999 & 1 & & & & & & & & & & \\
\hline 9 & 0.772 & 0.000 & 0.653 & 0.051 & 1 & 0.267 & 0.118 & 0.135 & & & & & & & & & \\
\hline 10 & 0.999 & 0.000 & 0.978 & 0.000 & 0.000 & 0.000 & 0.000 & 0.000 & 0.953 & & & & & & & & \\
\hline 11 & 0.000 & 0.000 & 0.000 & 0.000 & 1 & 0.000 & 0.000 & 0.001 & 1 & 0.000 & & & & & & & \\
\hline 12 & 0.001 & 0.000 & 0.001 & 0.000 & 0.953 & 0.000 & 0.000 & 0.001 & 1 & 0.047 & 0.997 & & & & & & \\
\hline 13 & 0.519 & 0.000 & 0.370 & 0.000 & 0.964 & 0.002 & 0.000 & 0.004 & 1 & 0.894 & 0.998 & 1 & & & & & \\
\hline 14 & 0.000 & 0.000 & 0.000 & 0.000 & 1 & 0.042 & 0.100 & 0.148 & 0.998 & 0.000 & 0.913 & 0.574 & 0.782 & & & & \\
\hline 15 & 0.133 & 0.000 & 0.508 & 0.000 & 0.000 & 0.000 & 0.000 & 0.000 & 0.065 & 0.012 & 0.000 & 0.000 & 0.006 & 0.000 & & & \\
\hline 16 & 0.000 & 0.000 & 0.000 & 0.000 & 0.000 & 0.000 & 0.000 & 0.000 & 0.001 & 0.000 & 0.000 & 0.000 & 0.000 & 0.000 & 0.614 & & \\
\hline 17 & 0.000 & 0.000 & 0.000 & 0.000 & 0.000 & 0.000 & 0.000 & 0.000 & 0.000 & 0.000 & 0.000 & 0.000 & 0.000 & 0.000 & 0.000 & 0.003 & ........ \\
\hline
\end{tabular}

$*$ The mean difference is significant at the 0.05 level

Legend: $1=$ Barbodes binotatus, $2=$ Crossocheilus oblongus, $3=$ Hampala macrolepidota, $4=$ Lobocheilos rhabdoura, $5=$ Mystacoleucus obtusirostris, $6=$ Neolissochilus soroides, $7=$ Osteochilus waandersii, $8=$ Poropuntius smedleyi, $9=$ Probarbus jullieni, $10=$ Puntius lateristrig, $11=$ Rasbora paviana, $12=$ Rasbora sumatrana, $13=$ Tor tambra, 14= Tor tambroides, 15= Channa lucius, 16= Channa striata, 17= Pristolepis grootii

TABLE 5. Multiple comparisons of L1/L2 among 17 species of fish that were caught by using Post-Hoc comparison test (Tukey HSD)

\begin{tabular}{|c|c|c|c|c|c|c|c|c|c|c|c|c|c|c|c|c|c|}
\hline \multirow{2}{*}{ 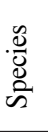 } & \multicolumn{17}{|c|}{ Significant value ( $\mathrm{P}$ value) } \\
\hline & 1 & 2 & 3 & 4 & 5 & 6 & 7 & 8 & 9 & 10 & 11 & 12 & 13 & 14 & 15 & 16 & 17 \\
\hline \multicolumn{18}{|l|}{1} \\
\hline 2 & 0.000 & & & & & & & & & & & & & & & & \\
\hline 3 & 1 & 0.000 & & & & & & & & & & & & & & & \\
\hline 4 & 0.000 & 0.999 & 0.000 & & & & & & & & & & & & & & \\
\hline 5 & 0.005 & 0.154 & 0.005 & 0.625 & & & & & & & & & & & & & \\
\hline 6 & 0.000 & 0.771 & 0.000 & 1 & 0.946 & & & & & & & & & & & & \\
\hline 7 & 0.000 & 0.999 & 0.000 & 1 & 0.863 & 1 & & & & & & & & & & & \\
\hline 8 & 0.001 & 1 & 0.001 & 1 & 0.994 & 1 & 1 & & & & & & & & & & \\
\hline 9 & 0.993 & 0.635 & 0.983 & 0.885 & 1 & 0.975 & 0.939 & 0.980 & & & & & & & & & \\
\hline 10 & 0.998 & 0.000 & 0.986 & 0.000 & 0.114 & 0.000 & 0.000 & 0.014 & 1 & & & & & & & & \\
\hline 11 & 0.000 & 0.000 & 0.000 & 0.001 & 1 & 0.024 & 0.064 & 0.909 & 1 & 0.000 & & & & & & & \\
\hline 12 & 0.256 & 0.000 & 0.202 & 0.006 & 0.999 & 0.050 & 0.046 & 0.596 & 1 & 0.893 & 0.997 & & & & & & \\
\hline 13 & 0.951 & 0.067 & 0.903 & 0.269 & 1 & 0.563 & 0.439 & 0.806 & 1 & 1 & 1 & 1 & & & & & \\
\hline 14 & 0.000 & 0.020 & 0.001 & 0.236 & 1 & 0.704 & 0.586 & 0.979 & 1 & 0.035 & 1 & 0.998 & 1 & & & & \\
\hline 15 & 0.590 & 0.000 & 0.890 & 0.000 & 0.000 & 0.000 & 0.000 & 0.000 & 0.594 & 0.104 & 0.000 & 0.003 & 0.212 & 0.000 & & & \\
\hline 16 & 0.000 & 0.000 & 0.000 & 0.000 & 0.000 & 0.000 & 0.000 & 0.000 & 0.014 & 0.000 & 0.000 & 0.000 & 0.000 & 0.000 & 0.250 & & \\
\hline 17 & 0.000 & 0.000 & 0.000 & 0.000 & 0.000 & 0.000 & 0.000 & 0.000 & 0.000 & 0.000 & 0.000 & 0.000 & 0.000 & 0.000 & 0.000 & 0.000 & ........ \\
\hline
\end{tabular}

$*=$ The mean difference is significant at the 0.05 level.

Legend: $1=$ Barbodes binotatus, $2=$ Crossocheilus oblongus, $3=$ Hampala macrolepidota, $4=$ Lobocheilos rhabdoura, $5=$ Mystacoleucus obtusirostris, $6=$ Neolissochilus soroides, $7=$ Osteochilus waandersii, $8=$ Poropuntius smedleyi, $9=$ Probarbus jullieni, $10=$ Puntius lateristrig, $11=$ Rasbora paviana, $12=$ Rasbora sumatrana, $13=$ Tor tambra, 14= Tor tambroides, 15= Channa lucius, 16= Channa striata, 17= Pristolepis grootii 
TABLE 6. Multiple comparisons of W/L among 17 species of fish that were caught by using Post-Hoc comparison test (Tukey HSD)

\begin{tabular}{|c|c|c|c|c|c|c|c|c|c|c|c|c|c|c|c|c|c|}
\hline \multirow{2}{*}{ 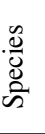 } & \multicolumn{17}{|c|}{ Significant value } \\
\hline & 1 & 2 & 3 & 4 & 5 & 6 & 7 & 8 & 9 & 10 & 11 & 12 & 13 & 14 & 15 & 16 & 17 \\
\hline 1 & & & & & & & & & & & & & & & & & \\
\hline 2 & 0.000 & & & & & & & & & & & & & & & & \\
\hline 3 & 0.996 & 0.000 & & & & & & & & & & & & & & & \\
\hline 4 & 0.000 & 0.068 & 0.000 & & & & & & & & & & & & & & \\
\hline 5 & 1 & 0.000 & 1 & 0.000 & & & & & & & & & & & & & \\
\hline 6 & 0.000 & 0.000 & 0.000 & 0.936 & 0.010 & & & & & & & & & & & & \\
\hline 7 & 0.000 & 0.063 & 0.000 & 1 & 0.003 & 1 & & & & & & & & & & & \\
\hline 8 & 0.996 & 0.002 & 1 & 0.372 & 1 & 0.901 & 0.664 & & & & & & & & & & \\
\hline 9 & 0.154 & 1 & 0.467 & 1 & 0.437 & 1 & 1 & 0.935 & & & & & & & & & \\
\hline 10 & 0.103 & 0.000 & 0.977 & 0.000 & 0.982 & 0.041 & 0.018 & 1 & 0.866 & & & & & & & & \\
\hline 11 & 1 & 0.000 & 0.947 & 0.000 & 1 & 0.000 & 0.000 & 0.988 & 0.108 & 0.011 & & & & & & & \\
\hline 12 & 1 & 0.000 & 0.996 & 0.000 & 1 & 0.000 & 0.000 & 0.992 & 0.151 & 0.385 & 1 & & & & & & \\
\hline 13 & 0.000 & 1 & 0.000 & 0.987 & 0.001 & 0.621 & 0.953 & 0.132 & 1 & 0.010 & 0.000 & 0000 & & & & & \\
\hline 14 & 0.000 & 1 & 0.000 & 0.849 & 0.000 & 0.055 & 0.707 & 0.029 & 1 & 0.000 & 0.000 & 0.000 & 1 & & & & \\
\hline 15 & 1 & 0.000 & 1 & 0.000 & 1 & 0.000 & 0.000 & 0.999 & 0.232 & 0.651 & 1 & 1 & 0.000 & 0.000 & & & \\
\hline 16 & 0.000 & 0.000 & 0.016 & 0.736 & 0.094 & 1 & 0.993 & 0.987 & 1 & 0.512 & 0.000 & 0.010 & 0.434 & 0.026 & 0.004 & & \\
\hline 17 & 0.000 & 0.000 & 0.000 & 0.000 & 0.007 & 0.000 & 0.000 & 0.015 & 0.000 & 0.000 & 0.000 & 0.067 & 0.000 & 0.000 & 0.012 & 0.000 & ........ \\
\hline
\end{tabular}

* $=$ The mean difference is significant at the 0.05 level

Legend: 1= Barbodes binotatus, $2=$ Crossocheilus oblongus, $3=$ Hampala macrolepidota, $4=$ Lobocheilos rhabdoura, $5=$ Mystacoleucus obtusirostris, $6=$ Neolissochilus soroides, $7=$ Osteochilus waandersii, $8=$ Poropuntius smedleyi, $9=$ Probarbus jullieni, $10=$ Puntius lateristrig, $11=$ Rasbora paviana, $12=$ Rasbora sumatrana, $13=$ Tor tambra, 14= Tor tambroides, 15= Channa lucius, 16= Channa striata, $17=$ Pristolepis grootii

TABLE 7. Key to species based on scale morphologies, morphometric and ratios formed related to length

1. Type of scale is cycloid

1. Type of scale is ctenoid

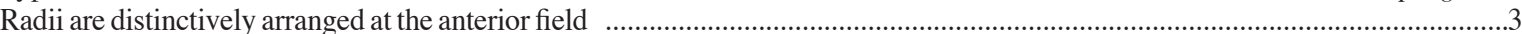

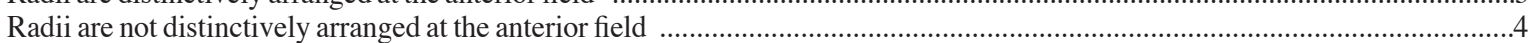

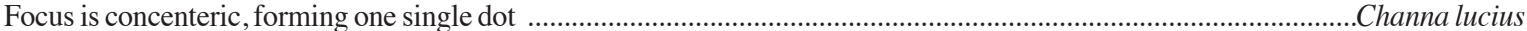

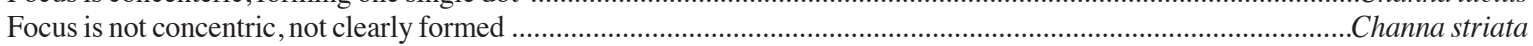

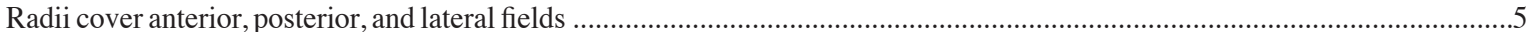

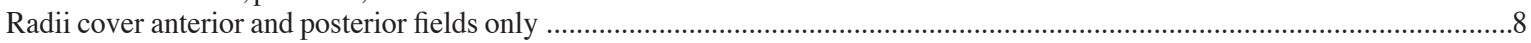

Radii are numerously arranged ...................................................................................................................Probarbus jullieni

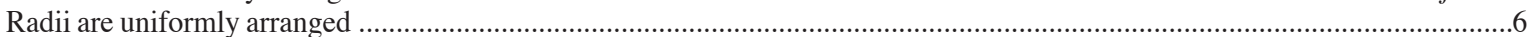

Overall scale shape is rectangular ......................................................................................................... Hampala macrolepidota

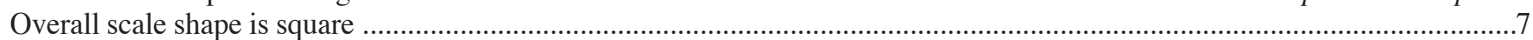

Range for ratio W/L is $0.852-1.291$; average value is 0.903 ; correlation coefficient is 0.971 ......................Barbodes binotatus

Range for ratio W/L is $0.775-1.094$; average value is 0.958 ; correlation coefficient is 0.883 .......................Puntius lateristriga

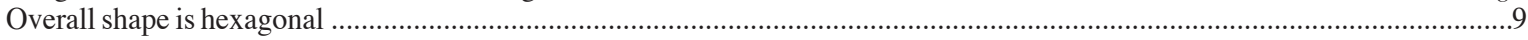

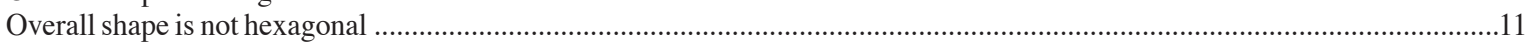

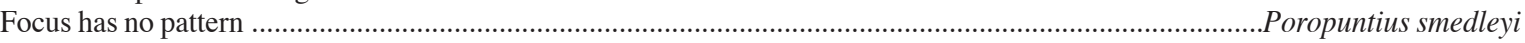

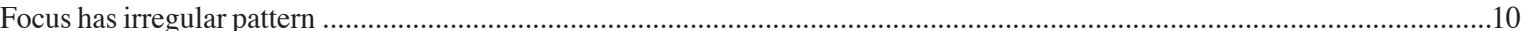

10. Focus is formed by irregular branching pattern ........................................................................................eolissochilus soroides

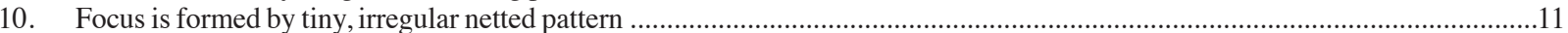

11. Range for ratio L1/L2 is $0.418-0.829$; average value is 0.651 ; correlation coefficient is 0.483 .................................Tor tambra

11. Range for ratio L1/L2 is $0.250-1.267$; average value is 0.520 ; correlation coefficient is 0.977 ........................Tor tambroides

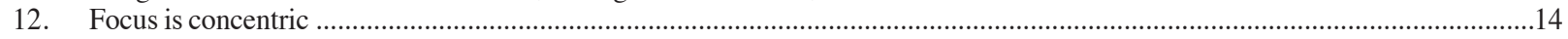

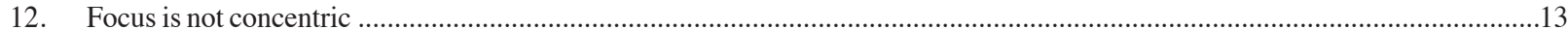

13. Focus pattern is irregular branching ........................................................................................................ steochilus waandersii

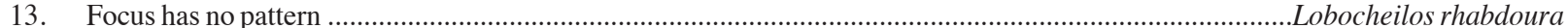

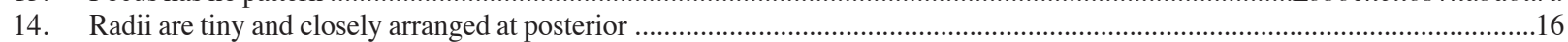

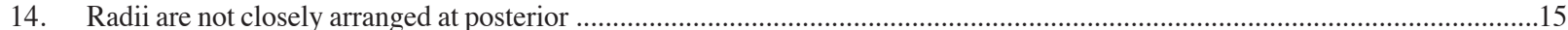

15. Range for ratio L1/L2 is $0.286-0.875$; average value is 0.535 ; correlation coefficient is 0.701 .

Rasbora paviana

15. Range for ratio L1/L2 is $0.348-1.293$; average value is 0.656 ; correlation coefficient is 0.964 ..................Rasbora sumatrana

16. Overall shape is rectangular..

16. Overall shape is oval....... Mystacoleucus obtusirostris Crossocheilus oblongus 


\section{ACKNOWLEDGEMENTS}

The authors are deeply indebted to Tenaga Nasional Berhad Research (TNBR) for permitting access to sampling sites and providing logistics throughout the fieldworks which was conducted during the construction of the Kenyir Second Dam, a part of Hulu Terengganu Hydroelectric Project (HTHEP). We also would like to thank the Department of Wildlife and National Park (DWNP) for lending us helping hands during the sampling sessions.

\section{REFERENCES}

April, J., Mayden, R.L., Hanner, R.H. \& Bernatchez, L. 2011. Genetic calibration of species diversity among North America's freshwater fishes. Proceeding of the National Academy of Sciences of the United States of America 108(26): 10602-10607.

Cadrin, S.X. 2000. Advances in morphometric identification of fishery stocks. Review in Fish Biology and Fisheries 10: 91-112.

Casselman, J.M., Collins, J.J., Crossman, E.J., Ihssen, P.E. \& Spangler, G.R. 1981. Lake Whitefish (Coregonuss clupeaformis) stocks of the Ontario waters of Lake Huron. Canadian Journal of Fisheries and Aquatic Sciences 38: 1772-1789.

Casteel, R.W. 1976. The scales of the native freshwater fish families of Washington. Northwest Science 47(4): 230-238.

Esmaeili, H.R., Hojat Ansari, T. \& Teimory, A. 2007. Scale structure of a cyprinid fish; Capoeta damascina (Valenciennes in Cuvier and Valenciennes, 1842) Using scanning electron microscope (SEM). Iranian Journal of Science \& Technology 31(A3): 255-262.

Ganzon, M.A.M., Torres, M.A.J., Gorospe, J.J. \& Demayo, C.G. 2012. Variations in scale morphology between sexes of the spotted barb, Barbodes binotatus (Valenciennes, 1842) (Actinopterygii: Cyprinidae) The Second International Conference on Environment and Bioscience 44: 80-84.

Goodrich, E.S. 1909. The vertebrata craniata (cyclostomes and fishes). In A Treatise on Zoology, Part 9, edited by Lankester, R. London: Adam \& Charles Black.

Harabawy, A.S.A., Mekkawy, I.A.A. \& Alkaladi, A. 2012. Identification of three fish species of genus Plectorhynchus from the Red Sea by their scale characteristics. Life Science Journal 9(4): 4472-4485.

Hutchinson, W.F., Carvalho, G.R. \& Rogers, S.I. 2001. Marked genetic structuring in localised spawning populations of cod Gadus morhua in the North Sea and adjoining waters, as revealed by microsatellites. Marine Ecology Progress Series 223: 251-260.

Ibanez, A.L. \& O'Higgins, P. 2011. Identifying fish scales: The influence of allometry on scale shape and classification. Fisheries Research 109: 54-60.

Ibanez, A.L., Cowx, I.G. \& O’Higgins, P. 2007. Geometric morphometric analysis of fish scales for identifying genera, species and local populations within Mugilidae. Canadian Journal of Fisheries and Aquatic Sciences 64: 1091-1100.
Ihssen, P.E., Brooke, H.E., Casselman, J.M., McGlade, J.M., Payne, N.R. \& Utter, F.M. 1981. Stock identification: Materials and method. Canadian Journal of Fisheries and Aquatic Sciences 38: 1838-1855.

Jhingran, V.G. 1957. Age determination of the Indian major carp, Cirrhinus mirgala (Ham.) by means of scales. Nature London 179(4557): 468-469.

Johal, M.S. 2005. Recent innovations in age determination using hard parts in Indian freshwater fishes. In New Horizons in Animal Sciences, edited by Sobti, R.C. \& Sharma,V.L. Jalandhar, Punjab: Visual Publishing Company. pp. 91-98.

Johal, M.S. \& Tandon, K.K. 1992. Age and growth of carp Catla catla (Hamilton, 1822) from Northern India. Fisheries Research 14: 83-90.

Kottelat, M., Whitten, A.J., Kartikasari, S.N. \& Wirjoatmodjo, S. 1993. Freshwater Fishes of Western Indonesia and Sulawesi. Singapore: Berkeley Books Singapore.

Mariani, S., Hutchinson, W.F., Hatfield, E.M.C., Ruzzante, D.E., Simmonds, E.J., Dahlgren, T.G., André, C., Brigham, J., Torstensen, E. \& Carvalho, G.R. 2005. North Sea herring population structure revealed by microsatellite analysis. Marine Ecology Progress Series 303: 245-257.

Mustafa, A. 2008. Laporan Kajian Inventori Spesies Ikan di Sungai Cicir, Hulu Terengganu. Pusat Penyelidikan Perikanan Air Tawar, Glami Lemi, Jelebu, Negeri Sembilan.

Patterson, R.T., Wright, C., Chang, A.S., Taylor, L.A., Lyons, P.D., Dallimore, A. \& Kumar, A. 2002. Atlas of common squamatological (fish scale) material in coastal British Columbia and an assessment of the utility of various scale types in paleofisheries reconstruction. Palaeontologia Electronica 4(1): 88.

Poulet, N., Reyjol, Y., Collier, H. \& Lek, S. 2005. Does fish scale morphology allow the identification of populations at a local scale? A case study for rostrum dace Leuciscus leuciscus burdigalensis in River Viaur (SW France). Aquatic Sciences 67: 122-127.

Schneider, J.C., Laarman, P.W. \& Gowing, H. 2000. Age and growth methods and state averages. In Chapter 9: Manual of Fisheries Survey Methods II: With Periodic Updates, edited by Schneider, J.C. Ann Arbor: Michigan Department of Natural Resources, Fisheries Special Report 25.

Winemiller, K.O., Agostinho, A.A. \& Caramaschi, E.P. 2008 Fish ecology in tropical streams. In Tropical Stream Ecology, edited by Dudgeon, D. London: Academic Press Publication. pp. 107-146.

School of Environmental and Natural Resource Sciences

Faculty of Science and Technology

Universiti Kebangsaan Malaysia

43600 UKM Bangi, Selangor Darul Ehsan

Malaysia

*Corresponding author; email: farahayuni@siswa.ukm.edu.my

Received: 31 August 2016

Accepted: 1 April 2017 